\title{
The Military Operation of the EU in Chad and the Central African Republic: Good Policy, Bad Politics
}

Citation for published version (APA):

Dijkstra, H. (2010). The Military Operation of the EU in Chad and the Central African Republic: Good Policy, Bad Politics. International Peacekeeping, 17(3), 395-407.

https://doi.org/10.1080/13533312.2010.500150

Document status and date:

Published: 22/09/2010

DOI:

10.1080/13533312.2010.500150

Document Version:

Accepted author manuscript (Peer reviewed / editorial board version)

Document license:

Unspecified

\section{Please check the document version of this publication:}

- A submitted manuscript is the version of the article upon submission and before peer-review. There can be important differences between the submitted version and the official published version of record.

People interested in the research are advised to contact the author for the final version of the publication, or visit the DOI to the publisher's website.

- The final author version and the galley proof are versions of the publication after peer review.

- The final published version features the final layout of the paper including the volume, issue and page numbers.

Link to publication

\footnotetext{
General rights rights.

- You may freely distribute the URL identifying the publication in the public portal. please follow below link for the End User Agreement:

www.umlib.nl/taverne-license

Take down policy

If you believe that this document breaches copyright please contact us at:

repository@maastrichtuniversity.nl

providing details and we will investigate your claim.
}

Copyright and moral rights for the publications made accessible in the public portal are retained by the authors and/or other copyright owners and it is a condition of accessing publications that users recognise and abide by the legal requirements associated with these

- Users may download and print one copy of any publication from the public portal for the purpose of private study or research.

- You may not further distribute the material or use it for any profit-making activity or commercial gain

If the publication is distributed under the terms of Article $25 \mathrm{fa}$ of the Dutch Copyright Act, indicated by the "Taverne" license above, 


\title{
The Military Operation of the $\mathrm{EU}$ in Chad and the Central African Republic: Good Policy, Bad Politics
}

\author{
HYLKE DIJKSTRA
}

2010

This is the final electronic version of an article published in:

International Peacekeeping 17(3): 395-407

\begin{abstract}
This article evaluates the military operation of the European Union in Chad and the Central African Republic in 2008-09. Despite a promising conceptual approach and close cooperation with the United Nations (UN), the operation created significant political problems between member states. It led to a split - France arguing that it carried too much of the burden and Germany and the United Kingdom sensing that they were sponsoring a pet project. When the UN failed to achieve its ambitious promises to establish a parallel presence and follow-on force, tensions arose with the $\mathrm{UN}$ as well. This type of operation is therefore unlikely to be repeated in the near future.
\end{abstract}

In January 2008, the European Union (EU) launched a military operation in eastern Chad and the Central African Republic (CAR) for the duration of exactly one year (EUFOR Tchad/RCA). Its mandate was to contribute to protecting refugees from the Darfur region and internally displaced people, to facilitate the delivery of humanitarian aid, and to contribute to the protection of UN personnel. ${ }^{1}$ The operation, in other words, contributed to a 'safe and secure environment'. It was innovative in that it joined up with the United Nations (UN) Mission in the Central African Republic and Chad (MINURCAT), which focused among other things on the training of local police, as part of a broader international multidimensional presence. After the one-year mandate expired, MINURCAT took over the military component. It became responsible for all facets of the multidimensional presence. After the handover, it was able to benefit from the improvements in the infrastructure made by EUFOR, the military structures that had been put in place, the rehatting of some 2,200 troops and continuous logistical support. ${ }^{2}$ Rather than building an operation from scratch, MINURCAT thus took over a well-functioning mission and was operational from day one.

This type of 'bridging operation', where the EU prepares the ground for the UN, is promising on a conceptual level. ${ }^{3}$ On paper the EU is more capable of rapid force generation than the UN. It also has the capabilities to professionally deploy troops to difficult areas of operation, where it can set up camp and declare initial operational capability quickly. The idea of a multidimensional

1 UN Security Council Resolution 1778, article 6(a).

2 EUFOR, Operation EUFOR Tchad/RCA, Paris: Mont Valérien, 2009.

3 In 2003 the EU had carried out the much smaller and shorter Operation Artemis, to prepare the ground for the UN in the Democratic Republic of the Congo. As a result, bridging operations were mentioned as one of the models for EU-UN cooperation in European Council, Presidency Report on EU-UN Co-operation in Military Crisis Management Operations: Elements of Implementation of the EU-UN Joint Declaration, Brussels, 2004. See also Thierry Tardy, 'EU-UN Cooperation in Peacekeeping: A Promising Relationship in a Constrained Environment', in Martin Ortega (ed.), The EU and the UN: Partners in Effective Multilateralism, Paris: EU Institute for Security Studies, 2005, pp.49-68. 
presence furthermore fits very well with the so-called comprehensive approach, which the EU cherishes. In addition, cooperation with the UN and 'effective multilateralism' rank high among European priorities. ${ }^{4}$ From a military-strategic and operational perspective, this one-year bridging mission was also quite a success. Never before had the EU sent so many troops to such a distant theatre, located some $4,500 \mathrm{~km}$ from Brussels and $2,000 \mathrm{~km}$ from the nearest seaport. ${ }^{5}$ It overcame these logistical challenges. This was a major achievement. In addition, EUFOR had to operate as an impartial actor in a local political minefield. Despite strong suspicions that it was supporting the incumbent regime, EUFOR carried out its balancing act surprisingly well. ${ }^{6}$

Despite a promising concept and effective military implementation, EUFOR was marked by significant political problems in Brussels and New York. Within the EU, the operation created a split between three powerful member states. Germany and the United Kingdom (UK) saw it as another pet project in support of Françafrique. While they eventually decided not to block the operation, they made clear that they would not contribute any forces and would keep the common costs to an absolute minimum. When these costs increased, and only French companies locally benefited from European tenders, this led to frustrations on the side of Germany and the UK. As a result, they have lost their appetite for further French initiatives. France, for its part, was happy to make a major contribution, but it expected more from the other member states, including Germany and the UK, which had been vocal about the Darfur situation (which was spilling over into Chad and the CAR). Most other member states were averse to participation. This demonstrated to France a lack of commitment to an ambitious European Security and Defence Policy (ESDP). As will be shown, it meant that France carried a much larger than foreseen military and financial burden.

Similarly, this operation created significant political tensions in the relationship between the EU and the UN. Either the UN did not meet its promises, or the Europeans had made overly ambitious planning assumptions about the UN's capabilities. In fact MINURCAT was so slow in its force generation and the training of local police that during most of the deployment of EUFOR there was no parallel police presence. This created a security vacuum within the refugee camps, for which EUFOR had not planned. Equally problematic was that the UN did not do its military planning and force generation in time for the handover. In part this reflected the resistance of the Chadian government to a UN peacekeeping operation, but the result was that the EU had to press the UN to get its work done. As EU documents point out, 'the exit strategy from [a bridging] operation is the arrival, in time, of a UN force'. ${ }^{7}$ Despite official rhetoric that cooperation had been 'exemplary', the handover was considered by the EU a 'nightmare', which came at the cost of good relations. ${ }^{8}$

As a consequence of these political problems such a large-scale bridging operation is unlikely to be repeated in the near future. ${ }^{9}$ This is unfortunate for various reasons. First, as pointed out above, it was a conceptually attractive model. Second, the EU and the UN reached new levels of

4 European Council, A Secure European in a Better World [European Security Strategy], Brussels, 2003. For a more sceptical view see, Bruno Charbonneau, 'What Is So Special about the EU? EU-UN Cooperation in Crisis Management in Africa', International Peacekeeping, Vol.16, No.4, pp.546-61.

5 Bjoern Seibert, 'African Adventure? Assessing the EU's Military Intervention in Chad and the Central African Republic', Massachusetts Institute of Technology Security Studies Program Working Paper, Nov. 2007.

6 Critics argue that EUFOR was not impartial because it gave the Chadian government the possibility to regroup. Charbonneau (see n.4 above); Patrick Berg, 'EUFOR Tchad/RCA: The EU Serving French Interests', in Muriel Asseburg and Ronja Kempin (eds), The EU as a Strategic Actor in the Realm of Security and Defence, Berlin: Stiftung Wissenschaft und Politik, 2009, pp.57-69. But President Déby's repeated annoyance with EUFOR for allowing anti-government rebels free passage and conversations between the French force commander and the French government on the conduct of the operation suggest that EUFOR was impartial (interviews with national, Council Secretariat and Commission officials in Brussels, autumn 2009, early 2010).

7 European Council (see n.3 above), para.10.

8 Martin Palouš, 'EU Presidency Statement on the Situation in Chad, the Central African Republic and the Subregion', UN Security Council, 24 April 2009; interviews with officials in Brussels, Jan. 2010.

9 The Lisbon Treaty may make day-to-day relations between the EU and the UN easier through a more prominent EU presence in New York, but it is unlikely to resolve the problems of a political nature. 
cooperation through joint fact-finding missions and substantial coordination during the initial planning of the multidimensional presence. It is worth noting that, as part of the comprehensive approach, the European Commission paid for much of the MINURCAT police-training mission. Third, the political tensions were partly the result of poor understanding between the participants. This article traces in detail the EUFOR policy process. It starts with the agenda-setting phase and concludes with the handover. It pays particular attention to the political dynamics of the operation. Analyses of the military planning process, the tremendous logistical challenges and the actual implementation are available elsewhere. ${ }^{10}$

\section{Agenda-setting}

The conflict in Darfur has been on international agendas since early 2003. The Sudanese government was, however, extremely effective in undermining any type of international response. The conflict led to approximately 250,000 refugees leaving for eastern Chad, where they met another 185,000 internally displaced persons (IDPs), who had been displaced by internal armed conflict and inter-ethnic violence. ${ }^{11}$ Yet the border between Darfur and eastern Chad is porous and they did not find a safe and secure environment there either. It was, in this context, that the UK and France asked the UN Department of Peacekeeping Operations (DPKO) to start planning an international multidimensional presence, which it did during the autumn of 2006 and early $2007 .{ }^{12}$ In its proposed plan, MINURCAT would comprise 10,900 personnel to create a safe and secure environment in the surroundings of the camps, carry out humanitarian tasks and train local Chadian police to guarantee minimal security within the camps. These plans were in an advanced stage, when the Chadian President, Idriss Déby, made it clear that the military part of the presence would not be welcome in his country. ${ }^{13}$

France had made a defence arrangement with Chad after its independence, had established a permanent bilateral military presence (Operation Epervier) in 1986, and had a vested interest in Chad's stability. ${ }^{14}$ With the French presidential elections and the appointment of Bernard Kouchner as foreign minister in May 2007, the Darfur conflict resumed its domestic significance in France. On his second day in office, 19 May, Kouchner convened a meeting to discuss various options. ${ }^{15}$ These were subsequently communicated to European partners on 21 May, in what one interviewee recalls as a 'vague document'. France furthermore requested an 'options paper' before the following Council of Ministers meeting in June. ${ }^{16}$ Germany, which at the time held the EU presidency, tried to keep the issue off the agenda due to other priorities, such as the final settlement of the constitutional debate. But France was persistent and at the end of May invited representatives from the Council Secretariat and the European Commission to its national military headquarters in Paris for a

10 Alexander Mattelaer, 'The Strategic Planning of EU Military Operations: The Case of EUFOR Tchad/RCA', Working Paper No.5, Institute for European Studies, 2008; Seibert (see n.5 above); Berg (see n.6 above); Damien Helly, 'EUFOR Tchad/RCA: The EU Military Operation in the Republic of Chad and in the Central African Republic (Operation EUFOR Tchad/RCA)', in Giovanni Grevi, Damien Helly and Daniel Keohane (eds), European Security and Defence Policy: The First 10 Years (1999-2009), Paris: EU Institute for Security Studies, 2009, pp.339-52; Oxfam, 'Mission Incomplete: Why Civilians Remain at Risk in Eastern Chad', Briefing Paper No.119, Oxfam, 2008.

11 International Crisis Group, 'Chad: A New Conflict Resolution Framework', Africa Report, No.144, 2008; International Displacement Monitoring Centre, 'Chad: IDPs in the East Facing Continuing Violence and Hardship', 21 Dec. 2009.

12 UN Security Council, 'Minutes of 5478th Meeting of the UN Security Council', 29 June 2006.

13 UN, 'Report of the Secretary-General on Chad and the Central African Republic', UN doc., S/2007/488, 10 Aug. 2007.

14 For French foreign policy in Chad, see Bruno Charbonneau, 'France', in David Black and Paul Williams (eds), The International Politics of Mass Atrocities: The Case of Darfur, London: Routledge, 2010, pp.213-31.

15 'Darfur is Kouchner's First “Guest” at Quai d'Orsay', Liberation, (Paris) 21 May 2007.

16 Interviews with Council Secretariat officials in Brussels, Dec. 2009, Jan 2010. 
preliminary briefing and to devise a comprehensive plan of action. ${ }^{17}$ Kouchner also met Déby on 10 June, and a UN Security Council delegation, which visited Chad at that time, was told that 'following discussions with Mr. Kouchner the President had agreed, in principle, to the deployment of an international military presence in eastern Chad composed of French and other EU forces ... a UN military presence ... could eventually be discussed as a second phase of a UN deployment'. ${ }^{18}$ The idea of a bridging operation thus gradually took shape.

The moment that Portugal took over the EU presidency from Germany in July 2007, a EUFOR intervention was revived. The Council Secretariat was as ambitious as France, because of a bureaucratic interest in launching further operations, and presented the member states with an indicative timetable for the military planning, which led to the adoption of the operational plan in October. ${ }^{19}$ Some of the other member states were clearly in less of a hurry. As a first step, they tasked the Council Secretariat and the Commission to draft a joint options paper to be presented to the Council in July. Officials in the Council Secretariat used the paper to focus attention squarely on eastern Chad and the CAR in order to support the activities of the UN. At the same time, they discarded other less realistic options (such as humanitarian corridors and no-fly zones), which were unlikely to receive Security Council blessing. ${ }^{20}$ France used the opportunity of the options paper to volunteer to be Framework Nation, providing some 40 per cent of the troops and making its Operation Headquarters available. It noted, however, that one of the other member states would have to accept the responsibility of operation commander ${ }^{21}$ Germany and the UK made explicitly clear that while they would not block an operation, they would also not contribute to it.

\section{Decision-making}

The joint Council Secretariat-Commission options paper of 13 July 2007 can be seen as the start of the decision-making process. The member states, however, never explicitly stated that action by the EU in eastern Chad was appropriate and that the Council Secretariat could thus start planning a military operation. ${ }^{22}$ Instead, all sorts of informal discussions were taking place over the summer in Brussels and the national capitals. With Germany and the UK stating that they would not contribute to this operation, France approached other member states about their willingness to make troops available. By putting the position of operation commander on the table, which was unprecedented in the European context, France hoped to offer a sweetener to other states. Swedish Foreign Minister Carl Bildt initially showed a keen interest in the operation, and France (mistakenly) read this as a signal that Sweden might make the Swedish-led Nordic Battle Group of 1,500 troops available. ${ }^{23}$ But after a visit to the region in early September, Bildt announced that Sweden would not contribute the Battle Group or accept the position of operation commander, as the mission was more challenging than expected.

However, the prospect of EUFOR had gained momentum due to French lobbying, and at the end of August an EU-led fact-finding mission consisting of various officials from the Council Secretariat, the Commission and the UN (comprising policy, planning, logistical and intelligence

17 Interview in Brussels, 2010. The General Secretariat of the Council is the main body responsible in the EU for early military planning. See Hylke Dijkstra, 'The Council Secretariat's Role in the Common Foreign and Security Policy', European Foreign Affairs Review, Vol.13, No.2, 2008, pp.149-66; Hylke Dijkstra, 'Explaining Variation in the Role of the EU Council Secretariat in First and Second Pillar Policy-Making', Journal of European Public Policy, Vol.17, No.4, 2010, pp.527-44.

$18 \mathrm{UN}$ (see n.13 above), paras.23, 25.

19 Interview with national officials in Brussels, Nov. 2009, Feb 2010; the adoption of the Operational Plan is the last stage of the planning process, after which the operation is directly launched.

20 Mattelaer (see n.10 above); interview with Council Secretariat official in Brussels, Dec. 2009.

21 René Rouquet and Ruhi Acikgöz, 'The European Union Mission in Chad: EUFOR Tchad/RCA', Explanatory Memorandum of the Assembly of the WEU, 6 May 2008, para. 72.

22 Mattelaer (see n.10 above); interview with national official in Brussels, Feb. 2010.

23 Interview with national official in Brussels, Feb. 2010. 
officers) went to eastern Chad and the CAR to analyse the situation. ${ }^{24}$ While in terms of EU-UN cooperation, this was quite a milestone, one interviewee from the Council Secretariat noted that, 'because [DPKO] had done the planning, they thought that we would do exactly the same. They wanted us to do the military part and they would do all the rest. It took us some time to explain to them that we would do it differently'. ${ }^{25}$ Another interviewee stated that 'some people said about the operation that we were providing the security umbrella for the UN to perform ... on the UN side they also had too high expectations of us, for example that we would provide them with escorts. But this was not our role, we were not their drivers. ${ }^{126}$ The fact-finding mission nevertheless led to the adoption of the Crisis Management Concept on 12 September 2007, the first formal EU planning document.

Another internal milestone for the EU during this early planning phase was the cooperation between the Council Secretariat and the Commission. Because the Commission had been involved in the process since the very beginning, it was in a position to make accompanying funds available up to some $€ 35$ million, in addition to the annual $€ 30$ million it was already spending on humanitarian aid in eastern Chad and the CAR. Most important in this respect was the Commission's financial support for the MINURCAT police-training mission. Before the end of 2007, it transferred $€ 10$ million to a trust fund; this was the bulk of the initial funding that allowed the UN to go ahead. The remaining $€ 25$ million were spent on medium-term development projects. Given that in all previous EU military operations combined the Commission had provided only about $€ 1$ million, its early involvement in EUFOR led to a truly comprehensive plan.

After the Crisis Management Concept, the EU had to formally adopt the Military Strategic Options. Four options were issued by the Council Secretariat on 12 September. Two of these were politically unfeasible, while the third created logistical problems. Thus the remaining option - to deploy four battalions at once - was quickly accepted on 4 October. ${ }^{27}$ All the options had included a preliminary reference to the common costs of the operation, including the running of the headquarters and costs relating to infrastructure, that were to be borne by all member states proportional to their gross national income irrespective of whether they provided troops. The EUFOR common costs were substantial, but when during the drafting of the Joint Action, the formal legal basis of the operation, the amount significantly increased Germany and the UK, as non-troop-contributing states, demanded an explanation. Their ministers had agreed to the amounts mentioned in the Military Strategic Options and they were now faced with an unpleasant fait accompli. This led to a heated debate over money at ambassador level, where all proposals by France to increase the scope of the common costs were rejected. ${ }^{28}$

The financial disputes grew more serious over time. While the Joint Action agreed on $€ 99.2$ million in common costs, this rose to $€ 120$ million in the Operation Commander's first budget. The total combined costs of the operation, which included the individual contributions of member states made through their troop contributions, increased from an estimate of $€ 450$ million to approximately $€ 1$ billion in November $2008 .{ }^{29}$ It is virtually impossible to calculate the expenses per member state, but France clearly accounted for the largest burden. Assuming a proportional cost model, and the initial French objective to contribute 40 per cent of the troops, the first estimation of costs must have been in the range of $€ 200$ million for France. Given that it eventually contributed over 50 per cent of the troops, it must have paid around $€ 500$ million for the operation instead.

24 Interviews with Council Secretariat, European Commission and UN officials in Brussels and telecons, Jan. 2010.

25 Interview with Council Secretariat official, Dec. 2009.

26 Interview with Council Secretariat official, Jan. 2010.

27 Option One was to train Chadian troops to provide security, which conflicted with the EU's impartiality requirement. Option Two was to deploy gradually, which was impossible because of the rainy season. Option Three was to deploy at once. Option Four was to focus mainly on the CAR, which was not what the member states wanted. Option Three was thus adopted. Mattelaer (see n.10 above).

28 France had hoped to move some individual costs to common costs in order to reduce its financial burden.

29 Helly (see n.10 above). 
From a French perspective, it was thus frustrating that while its national contribution went up by some $€ 300$ million, the other member states refused to include the cost of basic items, such as drinking water for the soldiers, under the common costs. ${ }^{30}$

In parallel with discussions over the military options in the EU, there was a debate in New York on the Security Council resolution authorizing EUFOR to deploy. In retrospect, this became the single most important document for the operation. Within the EU, the assumption had always been that EUFOR was a one-year bridging operation, after which MINURCAT would take over the military tasks. This end-date concept was attractive to most member states, not least Germany and the UK, who feared open-ended common cost increases. In all internal EU documents, it is crystal clear that EUFOR would leave exactly one year after initial deployment. The Chadian government, on the other hand, was not yet willing to have a peacekeeping operation on its territory. The Security Council resolution therefore had to be drafted with great skill to satisfy the EU member states as well as the Chadian government. In order to placate Chad, it was decided to postpone final decisions about the handover to a Mid-Mandate Review. ${ }^{31}$ France and the Council Secretariat were pleased with the results, because EUFOR could go ahead. But the EU did not get any guarantees about a follow-on force in Resolution $1778 .^{32}$

Following the Military Strategic Options and Sweden's rejection of the position of operation commander, the EU organised an informal force generation conference on 24 September. Alexander Mattelaer describes it as a 'disaster'. ${ }^{33}$ Apart from France, very few states were willing to contribute personnel, and President Nicholas Sarkozy had to call his counterparts in Europe. The position of operation commander was offered to Ireland during an informal meeting of defence ministers on 28-9 September. ${ }^{34}$ Ireland had so far been absent from the debates - and the future operation commander, Lt. Gen. Pat Nash, had left for a golfing holiday in South Africa and had to be recalled. In addition to the command position Ireland contributed some 500 troops. Sarkozy's phone calls also had success with Poland, which made a similar contribution. Other member states contributed smaller contingents, with the total almost adding up to the required number of troops.

However, the main problem in terms of force generation was with the 'enablers' (tactical air transport, medical facilities and other logistical support). ${ }^{35}$ Robust types of military transport helicopters that could operate in eastern Chad were in short supply or already committed to other operations. Medical facilities had to be of a high standard and contributions were expensive. Given the logistical challenges of launching an operation in the middle of Africa, total contributions were still short of requirements after four force generation conferences. Participants 'felt a break/make moment'. ${ }^{36}$ During the fifth, and final, conference, France decided to make up most of the shortfalls (including 520 troops for logistical support). ${ }^{37}$ On this basis, Lt. Gen. Nash decided to launch the operation while noting that 'it was not a luxury plan'. ${ }^{38}$ One other observer commented that 'he had to take a risk ... if you are waiting for all ducks to be lined up in the pond, it would never happen'. ${ }^{39}$ Only after a contributing 'third state', the Russian Federation, made four helicopters available (and operational in January 2009) could EUFOR operate more comfortably.

30 Interview in Brussels, Jan. 2010.

31 UN Security Council Resolution 1778, article 10.

32 Interview with Council Secretariat official in Brussels, Dec. 2009.

33 Mattelaer (see n.10 above), p. 17.

34 Interview with national official in Brussels, Oct. 2009.

35 Telephone interview with Operation Headquarters official, Dec. 2009.

36 Ibid.

37 Interview with national official in Brussels, Nov. 2009.

38 Interview with Operation Headquarters official in Brussels, Jan. 2010.

39 Telephone interview with Operation Headquarters official, Dec. 2009. 


\section{Implementation}

As for the implementation of the operation (with initial operating capability declared on 15 March 2008), it is important to note that the objectives of the EU were very modest. This was only to be expected given that EUFOR was in Chad for one year, that it had only 3,700 troops available to ensure a safe and secure environment for refugees, that it never had sufficient tactical airlift and that its area of operations was nearly $350,000 \mathrm{~km}^{2}$. In this respect it is difficult to assess success. A positive appraisal came from Oxfam, which noted in an early report that it 'believes that EUFOR has made many civilians feel safer through its activities, which include patrolling known dangerous routes, destroying unexploded ordnance, making contact with local leaders, and positioning itself defensively around civilians during rebel and government fighting'. ${ }^{40}$ This view was echoed by other non-governmental organizations (NGOs). ${ }^{41}$

However, others have pointed out that EUFOR was unable to protect the refugees, IDPs and humanitarian workers. ${ }^{42}$ But during most of its deployment there was no local parallel Chadian police force to provide even minimal security in the refugee camps. As part of the international multidimensional presence, MINURCAT was supposed to deploy police trainers to eastern Chad. It had, however, its own problems with the force generation of these trainers and the recruitment and the training of police took a long time. Only on 24 October 2008 were the first 29 local police officers deployed to the camps. ${ }^{43}$ Five months later, and thus after the handover, 667 local police officers had been deployed, still short of the target of $850 .{ }^{44}$ In other words, the EU had made overly ambitious planning assumptions, for the UN could not meet its promised policing target.

This caused serious difficulties for EUFOR. The division of labour had, after all, been that whereas EUFOR would be in charge of contributing to a safe and secure environment outside the camps, the local police would provide basic security within them. Banditry and human rights violations continued inside the camps and people expected EUFOR - being the only security actor present - to deal with it. But as a military force EUFOR had planned for armed confrontations with gangs of 100-200 people, not groups of two to four committing crimes within the camps. The dilemma was made public by the force commander in Chad, Brig. Gen. Jean-Philippe Ganascia.

There is a discrepancy between what contributed to the initial set-up of the forces deployed here and the actual reality. The background situation has changed enormously ... It is therefore essential that we adapt our methods of action in order to counteract the coupeurs de route [highwaymen] whilst still remaining within the framework we were given. ${ }^{45}$

While EUFOR could not entirely solve this problem with the means available, it did make some adaptations. ${ }^{46}$ Women and children being the main victims of human rights violations, it emphasised gender issues, for example. EUFOR also started to target areas where crime levels were high with intensive patrolling for a few weeks using its troops. Of course EUFOR could not provide a continuous, semi-permanent presence and had to keep on the move. ${ }^{47}$ The increased number of incidents, which had a large impact on the refugees and IDPs, is held as evidence of EUFOR's

40 Oxfam (see n.10 above).

41 Helly (see n.10 above).

42 Berg (see n.6 above).

43 UN, 'Report of the Secretary-General on Chad and the Central African Republic', UN doc., S/2008/760, 4 Dec. 2008.

44 UN, 'Report of the Secretary-General on Chad and the Central African Republic', UN doc., S/2009/199, 14 April 2009.

45 In an article in Le Figaro, 16 June 2008, cited by Oxfam (see n.10 above), pp.24-5.

46 Telephone interview with Operation Headquarters official, Dec. 2009.

47 Ibid. 
failure. ${ }^{48}$ Yet EUFOR was not prepared for policing tasks and inefficient UN deployment was the major cause of the problem that EUFOR was uncomfortable dealing with.

\section{Termination and Handover}

Before EUFOR could declare full operating capability on 17 September 2008 it started the MidMandate Review process, which would eventually lead to the termination of the operation and the handover to MINURCAT on 15 March $2009 .{ }^{49}$ This process was conducted jointly by the EU and the UN during a trip to the region (19-25 June 2008).$^{50}$ Officials from both organizations discussed the review's terms of reference, and subsequently wrote separate reports: one by Javier Solana for the UN Secretary-General and the other by the Secretary-General of the UN to the Security Council. ${ }^{51}$ The reports were discussed by the UN Security Council on 24 September 2008 on the occasion of the adoption of Security Council Resolution 1834, which started the handover process.

Javier Solana, Bernard Kouchner, and the Belgian Foreign Minister, Karel de Gucht, attended the meeting. This was quite remarkable, as the Security Council normally meets at ambassador level. Javier Solana had not been overly involved in the EUFOR operation, and, apart from a visit to Chad in May 2008 and the attendance of the ceremony for the EU's first casualty in Paris, he had been largely absent from the whole process. However, because it was in the EU's interests to get out of Chad by the envisaged date of 15 March 2009, this message had to be clearly communicated to the UN. Given that the deployment of police trainers by MINURCAT was already far behind schedule, the Mid-Mandate Review was an appropriate time to reinforce the deadline. During his intervention, Solana noted that

EUFOR will leave on the 15th of March 2009. Our concern is to prevent a security gap at that moment. For this reason, I believe it is fundamental to insist on [these] aspects: an appropriate handover of the EUFOR by UN is an absolute necessity by the 15th of March 2009 ... a quick decision from the Security Council is needed. It will enable the UN to start its planning on time. We will do our best to support the UN in all areas and thus to make of this transition a success. ${ }^{52}$

UN Security Council Resolution 1834 asked for a report of the Secretary-General by 15 November on 'the planning and conducting preparations ... of the proposed UN military presence in the northeastern Central African Republic to take over EUFOR's presence', and a final decision on that matter on 15 December. ${ }^{53}$

With less than six months to the eventual handover, there was little time for the UN to do the planning and to raise sufficient forces for its operation. It did, however, send almost immediately a technical assessment mission to the region (6-13 October 2008). ${ }^{54}$ This was followed by the Under Secretary-General for Peacekeeping Operations (13-15 October), by intense discussions in New York with the Chadian Permanent Representative, by visits by the Under Secretary-General for Field Support (3-6 November) and by the Military Adviser for Peacekeeping Operations (12-14 November). ${ }^{55}$ However, President Déby remained reluctant to allow UN peacekeepers into Chad

48 Berg (see n.6 above).

49 EUFOR declared the elements deployed as fully operational, but they never actually reached full operating capability because the force generation process was never completed as a result of a lack of enablers.

50 UN, 'Report of the Secretary-General on Chad and the Central African Republic', UN doc., S/2008/601, 12 Sept. 2008.

51 Interview with Council Secretariat official in Brussels, Jan. 2010.

52 Javier Solana, 'Intervention de Javier SOLANA sur EUFOR Tchad/RCA', UN Security Council, 24 Sept. 2008 (author's trans.).

53 Articles 8, 10.

54 UN, 'Report of the Secretary-General' (see n.43 above).

55 Ibid. 
and raised objections in all discussions. Only after a meeting with Secretary-General Ban Ki-Moon on 26 November did he agree to a much smaller presence than foreseen in the UN. ${ }^{56}$ The UN Secretary-General's report arrived three weeks late on 4 December. The Security Council could only adopt Resolution 1861, which finally decided on the handover, on 14 January 2009, only two months before the handover had to take place.

It is worth noting that in addition to the reluctance of the Chadian government, despite all the visits to Chad by senior UN officials, it was felt in the EU that the UN 'did not have an appetite to do the operation' ${ }^{57}$ Another interviewee from the Council Secretariat similarly noted that

the UN spent all its time trying not to take over the operation. We tried, on the other hand, to make it effective on the day as scheduled. It was really difficult to get the UN involved. We used all the levers, with the Solana report, with [the Under-Secretary-General for Peacekeeping Operations] coming to Brussels. ${ }^{58}$

Given that nothing about the handover had been formally mentioned in the initial Security Council Resolution 1778, the EU was in an awkward position. When it appeared that the UN would not be ready for the handover, the UN maintained that it was the EU's problem. This was disputed and, as one observer notes, the 'French effectively forced them ... they forced DPKO to get in. It also came at the cost of good relations'. The handover was considered a 'nightmare'. ${ }^{59}$

There were three reasons why the handover eventually took place on time. First, various states contributing to EUFOR were persuaded by the Operation Headquarters to rehat some of their troops to be part of the MINURCAT operation, at least for a short time. ${ }^{60}$ On the day of the handover about 60 per cent of EUFOR, some 2,200 troops, moved to MINURCAT. Second, EUFOR continued to provide logistical support to MINURCAT for the beginning of its operation. Third, EUFOR decided to hand over all the infrastructure and assets to the Chadian authorities in line with the Status of Forces Agreement. This would create a point of no return, because without infrastructure and assets EUFOR could no longer fulfil its mandate. MINURCAT, in turn, had to negotiate with the Chadian government about making use of the infrastructure. An optimum process would have been for the EU to hand it over directly to the UN, but given the lateness of the new Security Council resolution this was not possible. Following the provisions of the original Status of Forces Agreement was, in the words of one interviewee, 'the safest way to ensure that [EUFOR] could leave' on 15 March 2009.

Handing over the infrastructure to the Chadian government, however, created one specific problem. As part of an informal gentlemen's agreement, the EU had negotiated with the UN that MINURCAT would pay part of the costs that EUFOR had invested in upgrading the local infrastructure (such as military camps). This was in total $€ 70$ million and was part of the common costs. However, nothing had been put in writing and in the final calculations the EU used a different depreciation model than the UN. Eventually, the UN paid for only 20 per cent of the $€ 70$ million. ${ }^{61}$ The episode not only illustrates the tensions in the relationship with the UN; it also shows the political problems within the EU. Since the infrastructure was paid via the common costs, the nonpayment affected Germany most, which had had great reservations about the operation in the first place.

56 UN Security Council, 'Minutes of 6042nd Meeting of the UN Security Council', 12 Dec. 2008.

57 Interview in Brussels, Jan. 2010.

58 Interview with Council Secretariat official in Brussels, Dec. 2009.

59 Interview in Brussels, Jan. 2010.

60 The possibility of rehatting was explicitly mentioned in earlier documents on EU-UN cooperation (see n.3 above).

61 Interview with Council Secretariat official in Brussels, Jan. 2010. 


\section{Concluding Observations}

This article has offered an overview of the political dynamics of the EUFOR Tchad/RCA operation. It was a promising concept, as a bridging operation to provide a linked intervention. During the planning of the operation, the EU and the UN also reached new milestones with joint fact-finding missions and permanent contacts and repeated visits between New York, Brussels and the Operation Headquarters in Paris. Getting the Commission involved from the very beginning was quite a watershed for the EU internally as well. It had tangible effects in terms of the comprehensive approach, which foresaw not only a military presence, but also police trainers. Not only did the Commission pay for much of the parallel MINURCAT deployment; it also made its substantial experience with humanitarian aid available to EU member states. Finally, on a military level, the EU managed to deploy in a very remote area of operations with modest means.

Nevertheless, the operation was undermined by problems of a political nature. EUFOR led to a significant split between member states and created tensions in the relationship with the UN. One official downplayed these problems as 'frictions', which are part of any multinational peacekeeping operation. ${ }^{62}$ Yet it was perhaps more fundamental than that. Due to the problems within the EU about EUFOR, substantial military operations in Africa in the near future have become unlikely. The budgets for the common costs of future operations will likely be small, thereby limiting ambitions. In addition, the EU is unlikely to plan an operation on the assumption that the UN will provide a parallel police-training mission. Further bridging operations are likely to be carried out in the future only if the EU has firm commitments about the military follow-on force. Yet, given that many states are reluctant to host UN peacekeepers, the UN may not be in the position to give firm commitments in advance. All these things combined make it unlikely that a similar type of operation will be undertaken in the near future. A more realistic concept would include a much smaller European footprint that prepares the ground for the UN. ${ }^{63}$

The disputes had to do not only with conflicting preferences, but also with a lack of understanding between the actors. A hostile view is that

Chad was a manufactured operation; it resulted from the desire of the new French President and Foreign Minister to present their ESDP credentials. It had nothing to do with a collective decision of the EU on the need to act in the light of a new crisis in Africa. That crisis had been going on for years, and then two new people arrived on the scene and decided for political reasons to promote some European activity. ${ }^{64}$

Nobody doubts that France had an interest in the operation beyond humanitarian concerns, but to portray Bernard Kouchner - the co-founder of Médecins Sans Frontières, who had given most of his life to the humanitarian community - as politically motivated, is undoubtedly harsh. Germany and the UK were unwilling to accept that French policy might have been partly driven by a mixture of altruism and domestic politics, the Darfur conflict being a hot topic in the French presidential elections. ${ }^{65}$

Similarly, in the relationship with the UN, Déby's resistance to UN peacekeepers was significant, motivated by reasons of sovereignty and because it could weaken his position vis-à-vis the rebels and neighbouring states. It had taken French leverage and three high-level visits by UN personnel as well as a bilateral meeting between the Secretary-General and Déby to get the handover by MINURCAT established. Furthermore, the Chadian government asked MINURCAT

62 Interview with national official in Brussels, Oct. 2009.

63 Interview with Council Secretariat official in Brussels, Jan. 2010.

64 British officer quoted in Luis Simón, 'Command and Control? Planning for EU military Operations', Occasional Paper No.81, EU Institute for Security Studies, Jan. 2010, p.36.

65 Mattelaer (see n.10 above), pp.15-16, quotes an official from a neutral EU state as saying 'by and large, we believe the French are honest about this and trying to do the right thing'. 
not to renew its mandate in 2010. The EU cavilled at the UN's inability to get its force generation ready on time. But it was clear that the UN had its hands tied, and so handover problems should have been foreseeable.

EUFOR Tchad/RCA was a significant step in the development of the military side of the ESDP. It was the largest autonomous military operation to date and its area of operation was in a remote part of Africa. The EU learnt practical lessons in logistic support, reached new levels of dayto-day cooperation with the $\mathrm{UN}$, and applied a comprehensive approach to crisis management through the various financial instruments of the Commission. At the same time the experience exposed the limits of EU-UN cooperation and the selective military ambitions of some of EU member states. This is explained by the different interests of the actors, and also by a lack of understanding between different actors. Despite its promise as an experiment in bridging between operations EUFOR is therefore unlikely to be repeated in the near future.

\section{ACKNOWLEDGEMENTS}

This article has benefited from 15 in-depth interviews with officials from the EU member states, EU institutions and the UN, as well as a seminar on lessons learnt in Brussels. 